\title{
A CASE OF INTRA-OCULAR NEUROMA (VON RECKLINGHAUSEN'S DISEASE) OF THE LEFT OPTIC NERVE HEAD
}

BY

\author{
H. B. Stallard \\ LONDON
}

Von ReCKlinghausen's disease is congenital, slowly progressive and affects males more commonly than females. Ocular complications are evident in some cases of this disease. The characteristic pathological changes are confined to and diffused throughout the distribution of one or more contiguous nerves or a plexus of nerves. The branches of the first division of the fifth cranial nerve, the optic nerve and the nerves to extra-ocular muscles are sometimes affected.

In the orbit the branches of the first division of the fifth become enlarged and convoluted and on palpation of the orbital contents they give the impression of feeling like a bag of worms. The eye on the affected side is proptosed and displaced, often downwards and forwards. Ptosis is evident, the skin of the lids is hypertrophied, the epitheiium is thickened, the papillae are enlarged and numerous and there is fibrous tissue hyperplasia in the corium. In some cases the affected area of skin is very hairy and pigmented. The Meibomian glands are widely separated by hypertrophied fibrous tissue, they are irregular in shape and size, contain degenerate vacuolated cells and are surrounded by a few round cells and giant cells which are also present beneath the skin. The blood vessels are numerous, congested and dilated. The circumference of the orbital margin is increased and the orbital walls become thin from pressure atrophy. In severe cases the bony wall is absent posteriorly and the orbital contents are in direct contact with the intracranial structures. This explains the pulsatile exophthalmos, which is not expansile as in an aneurysm in the cavernous sinus; no bruit is audible, and by pressure it may become converted into a pulsatile enophthalmos. In some cases the pulsatile exophthalmos has misled a surgeon into ligaturing the common carotid artery on the affected side. The exophthalmos is worse on excitement. The temporal fossae are full and buiging and on the affected side a doughy sensation is felt on palpation.

The skull is enlarged, brachycephalic, and the foramina through which the diseased nerves pass are grooved or enlarged.

When the ciliary nerves are affected they are enlarged and convoluted before piercing the sclera, but on traversing this structure they resume their normal thickness to revert to their pathological 
state on reaching the uveal tract. The choroid is thickened, its stroma is hypertrophied and its vascular character very reduced, the blood vessels being very few and less conspicuous than in the normal choroid. The stroma contains a mass of nucleated fibrous tissue cells and many branched pigment cells. The nerve endings are enlarged, in their centre are convoluted fibres; they are surrounded by a capsule composed of a single layer of flattened nucleated cells and there is a space between this and the surrounding tissues.

Associated with neurofibromatosis of the ciliary nerves is buphthalmos (infantile glaucoma). An interesting example of the appearance of glaucoma later in life in a subsequent generation affected by von Recklinghausen's disease is given in Achermann's case of a male who at the age of six had the right eye excised for buphthalmos. He had neurofibromatosis of the right upper eyelid and later developed diffuse von Recklinghausen's disease. His son at the age of ten had diffuse von Recklinghausen's disease with no involvement of the lids and at the age of thirty-four years chronic glaucoma developed in the left eye and when he was forty-four years old the right eye became glaucomatous. The latter's son (grandson of the original patient) showed no evidence of von Recklinghausen's disease or glaucoma.

Neurofibromatosis may also affect the nerves of the iris and with slit-lamp microscopy small nodules have been noted on some of the corneal nerves. Similar changes have also been observed in the nerves traversing the outer layers of the sclera.

When the optic nerve is affected by neurofibromatosis both the orbital and intracranial part may be involved causing proptosis and enlargement of the optic foramen and canal. The growth may be pear-shaped with its base towards the globe, or fusiform. Fibrous tissue and glial proliferation, areas of myxomatous degeneration and small cysts are some of the pathological features of neurofibromatosis of the optic nerve. Small greyishwhite nodules composed of neurofibrils, neurocytes, glial tissue, cysts and in some cases areas of degeneration and angiomatous elements, may be present on the edge of the optic disc and in the retina but these are rare. The case described below concerns such a lesion affecting the optic nerve head in one eye in a young male, aged 19, who had a marked family history of von Recklinghausen's disease affecting two generations of his forebears and who subsequently died three years later from a subtentorial growth which affected his hearing and gait.

It is well known that café au lait patches in the skin, bronzing, shagreen areas, freckles, moles and naevi are seen in association with von Recklinghausen's disease. Goldstein and Wexler have noted melanoma of the iris and melanosis uveae in connection with 


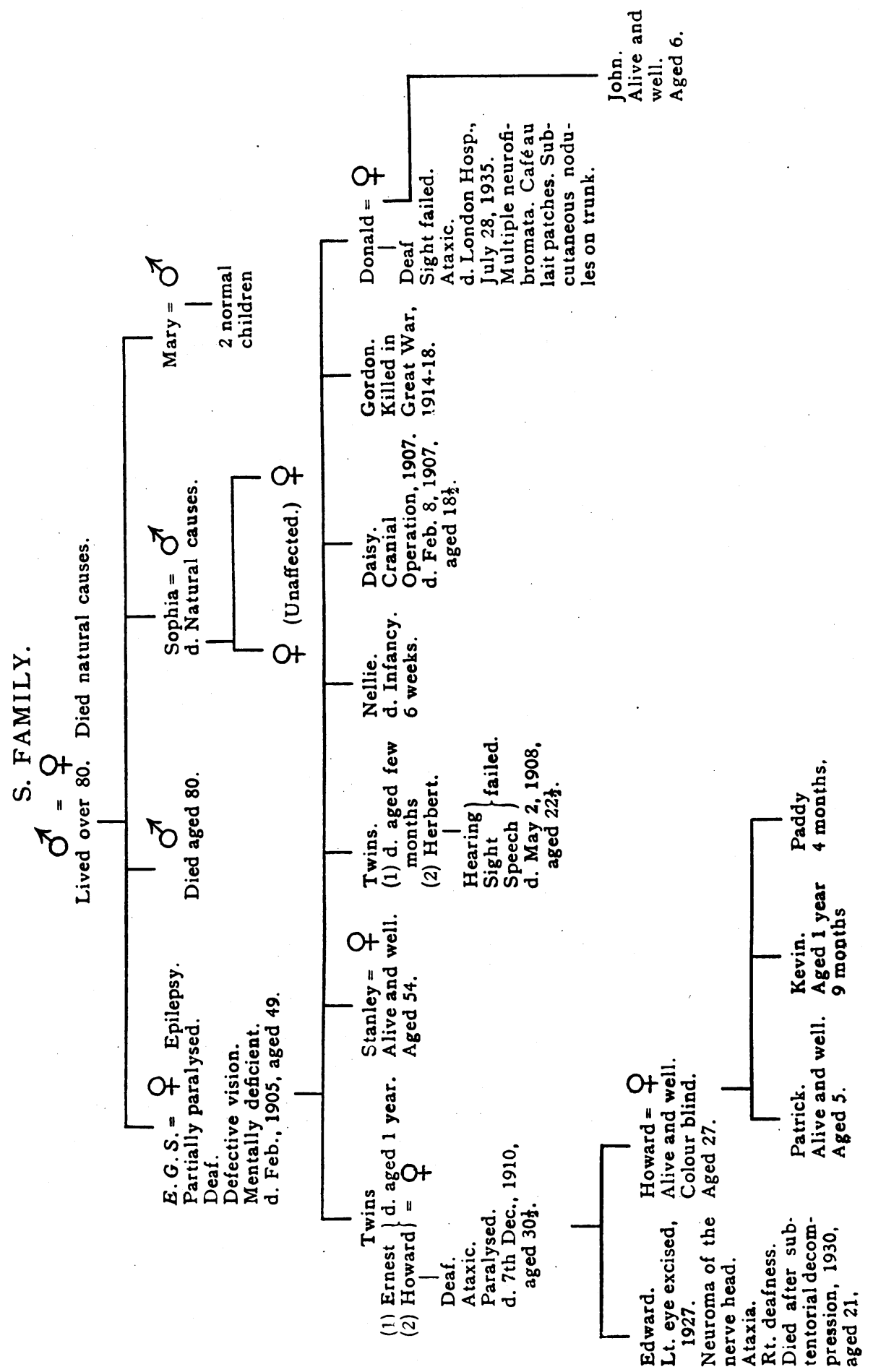


von Recklinghausen's disease, and several authors have commented on the presence of medullated nerve fibres in the retina in this disease. Copeland, Graves and Reese have noted that in persons showing the association of von Recklinghausen's disease and opaque nerve fibres there is a relatively greater incidence of abnormalities of the central nervous system and psychopathic disturbances. Shapland and Greenfield have reported a case of intracranial neurofibromatosis associated with a meningeal tumour of the middle cranial fossa which had spread into the optic nerve on the same side. In some cases sarcoma becomes superimposed on neurofibromatosis. Ocular palsies may arise from involvement of the $3 \mathrm{rd}$. 4th and 6 th cranial nerves.

Case Report.-E.S., aged 19 years, a clerk, attended the ophthalmic department at St. Bartholomew's Hospital, under the care of Mr. Rupert Scott (whose House-surgeon I was at this time) on June 17th, $192 \pi$, complaining that for $2-3$ weeks the left vision had been "smudgy." He was in good general health and had not lost weight.

Family History (See Table A).-E.G.S. in the first generation had been subject to epileptic fits in his youth. He became deaf, squinted and later was affected mentally. From the autumn of 1904 to February, 1905, his condition became progressively worse, his sight failed, his limbs became paralysed and he died in February, 1905, at the age of 49 years.

'This patient's father and mother were alive at his death, they lived to be over 80 years of age and died of natural causes. E.G.S. had a brother who lived to be over 80 years of age and left a " large healthy family," and two sisters, Sophia and Mary. Sophia had two daughters and Mary two children, all of whom were unaffected by von Recklinghausen's disease. Sophia died of " natural causes" early in her married life. In the second generation, the first born were twins, one died at the age of one year, the cause of death is unknown. The other twin, Howard, at the age of 29 years became deaf, ataxic and was unable to use his hands, he became paralysed and died at the age of 30 years and 6 months. The second child in this generation, Stanley, is now aged 54 years, is alive and well, married but has no family. Then came twins, one of whom died aged a few months, the cause of death being unknown. The other twin, Herbert, grew to be $6 \mathrm{ft} .2 \mathrm{in}$. in height and at the age of fourteen his hearing, sight and speech began to fail. At 20 years of age he could only get about with help, his speech could scarcely be understood and communication had to be made with large white letters on a black background held close to his eyes. He lost control of his saliva. He died aged $22 \frac{1}{2}$ years.

The next child, Nellie, died aged 6 weeks, the cause of death 


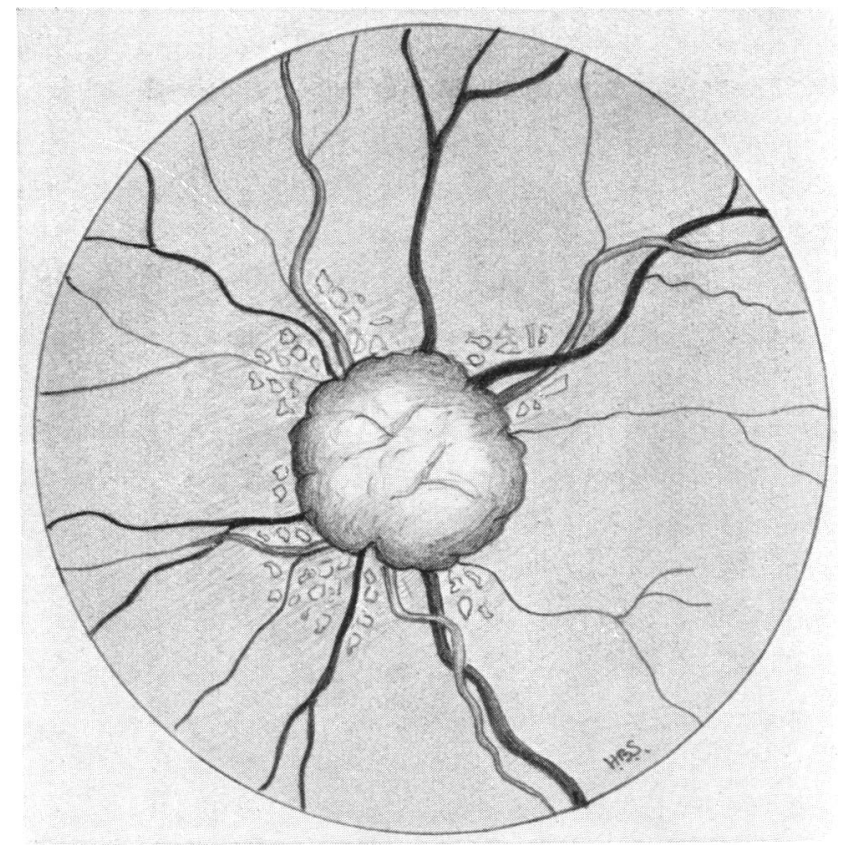

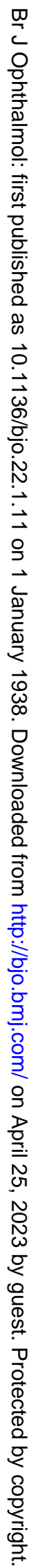

Microphotograph of a horizontal section through the left eye. The neoplasm arising from the optic nerve head is shown. 


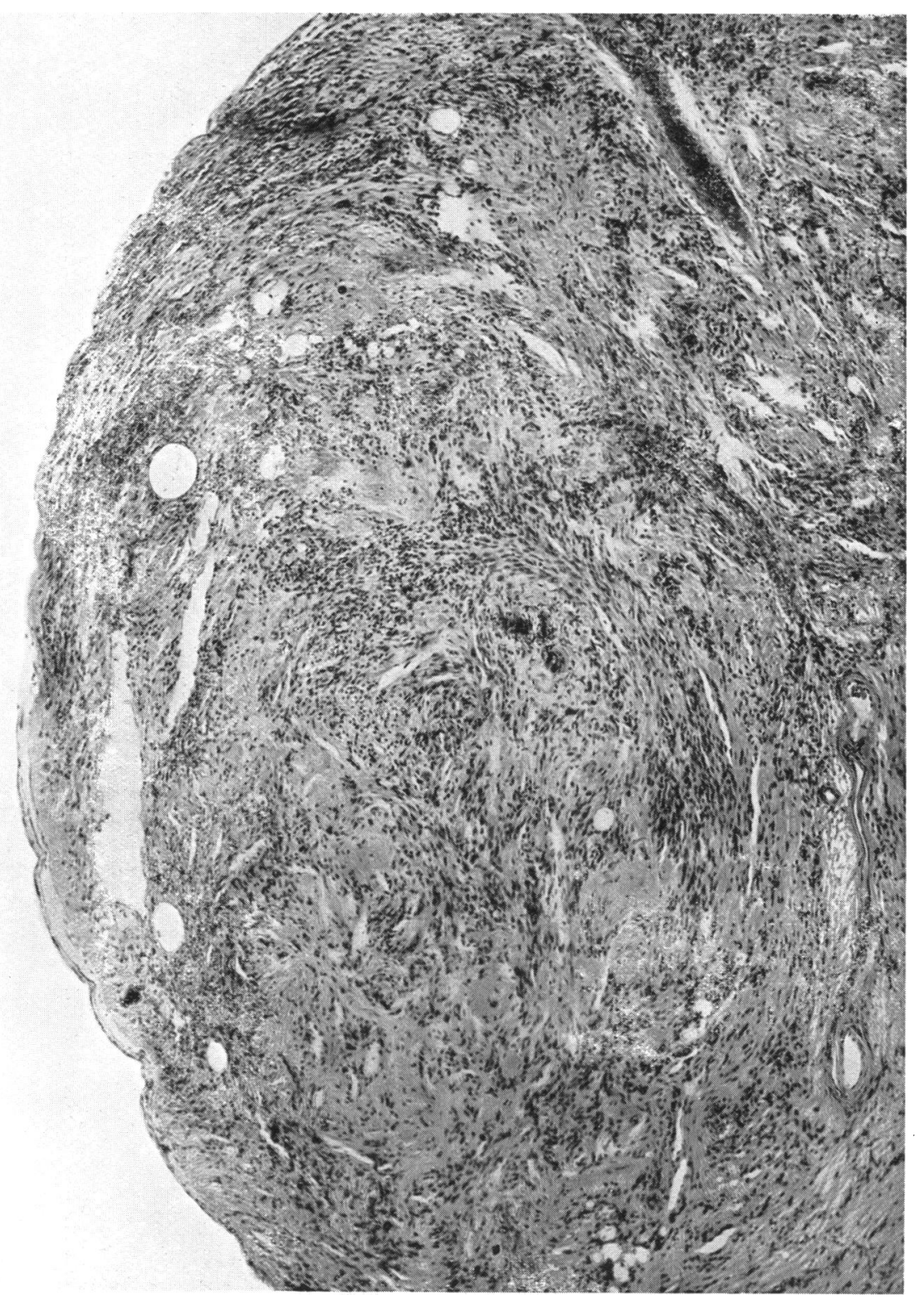

告 ल

ते $\overrightarrow{0}$

官

ง.

근응.

잉

$\therefore$ NN

ह.

$\underline{\Xi}$

क 출을

可

ธี ฆ

究

吅登

焉

i.

ن 0 崖

도인

롫

얼

농 ํํำ

웡

긍

은

我 굴

워뭉

그음

Nㅜ응.

$\times$ 등

도록

응

วิ응

웡

은 윽

क्ष क्ष

엉 유므.

跑

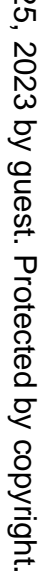




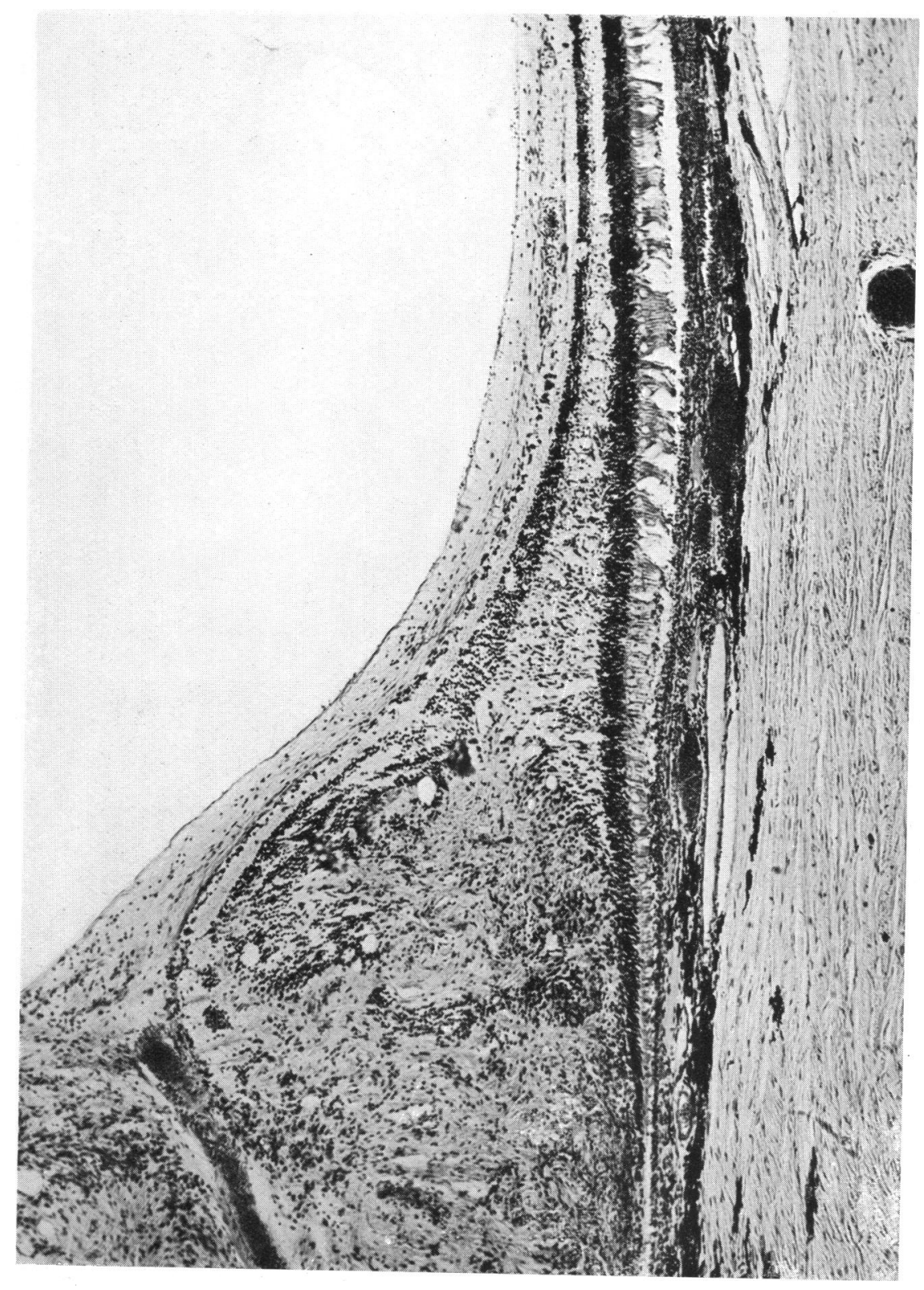

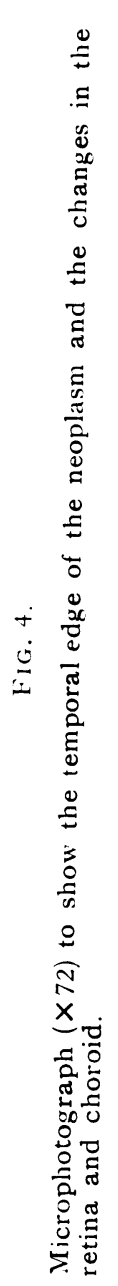




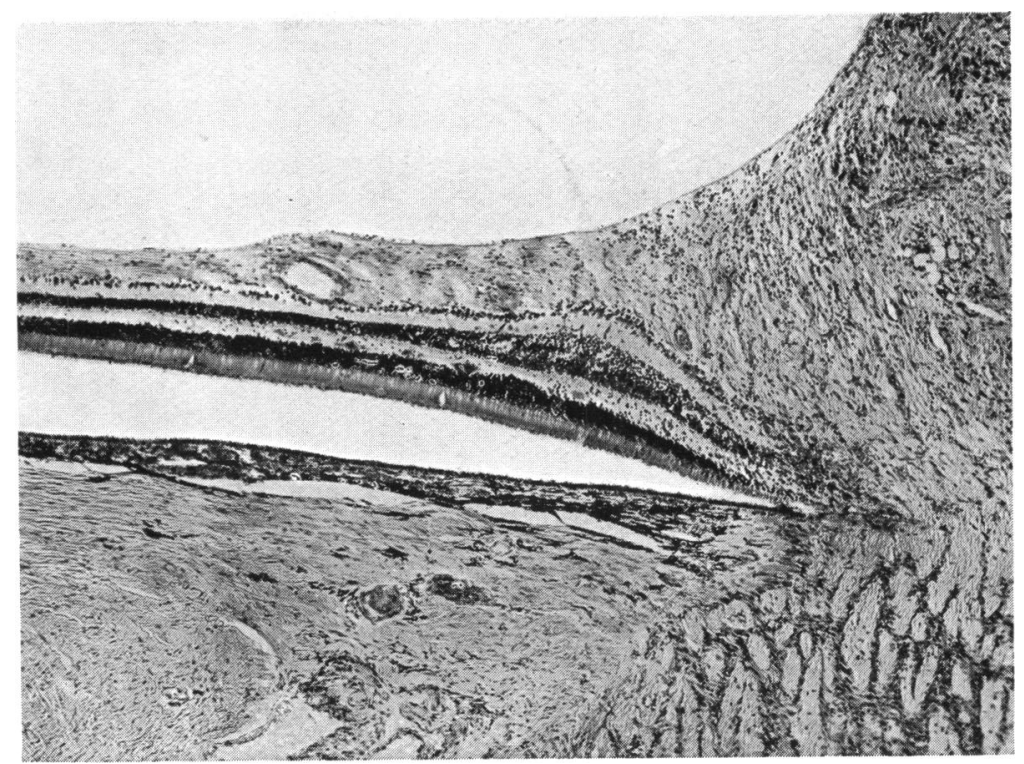

Fig. 5.

Microphotograph of the nasal edge of the neop'asm showing a cluster of small cysts

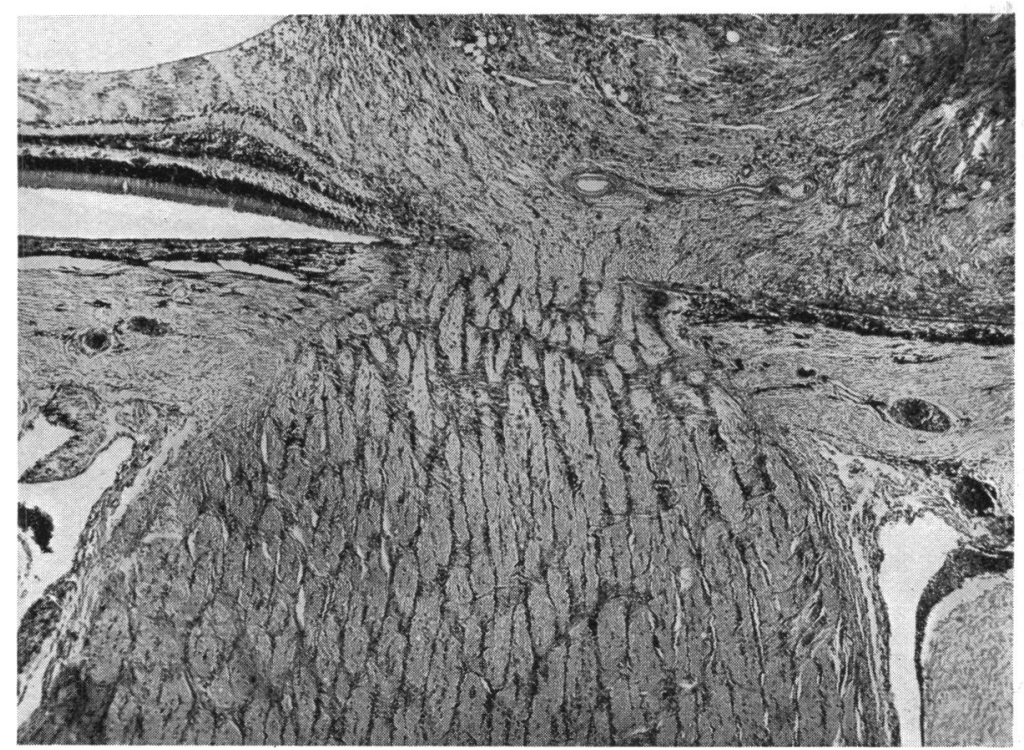

Fig. 6.

Microphotograph showing the base of the neoplasm. On the temforal side, the retina is extensively destroyed and the choroid compressed. The lamina cribrosa and optic nerve have not been infiltrated by the neoplasm. 
being unknown. Then came Daisy, who was well until she was 18 years of age when her fingers became stiff, and she was languid, nervous, somnolent and without energy. She died at the age of $18 \frac{1}{2}$ years after an intracranial operation. I have been unable to trace any clinical data about her at the hospital she attended. Gordon was killed in the European War, 1914-1918. Donald, the last child of this generation, at the age of 37 became deaf, ataxic and his sight failed. He died in the London Hospital aged $38 \frac{1}{2}$ years after an intracranial operation. His son John is now aged 6 and is alive and well.

Also in the third generation is E.S., the patient whose case is described in this paper. His brother Howard is aged 27, colourblind, alive and well and married. He has three children, Patrick aged 5, Kevin aged 1 year 9 months, and Paddy a girl aged 4 months. These children are well and up to the present show no evidence of neurofibromatosis.

Condition on Examination.-The left eye of E.S. was slightly divergent and there was also a slight degree of ptosis. 'The left vision was $6 / 18$ with correction. Fig. 1 is a drawing of the left optic disc and its adjacent structures. Projecting forwards from the optic disc was a hemispherical mass of newly formed tissue, greyish in colour with a nodular surface, and ill-defined outline and edges. Some small irregular flecks of exudate were present in the retina adjacent to the optic disc, particularly on the nasal side and near the main branches of the central retinal vessels. The retinal veins were dilated and engorged with blood. The peripheral visual field was full but there was a paracentral scotoma on the temporal side involving the blind spot and extending towards the fixation point and also downwards. The right eye was normal, the right vision being 6/6. A general medical examination revealed no abnormality. A malignant neoplasm of the left optic nerve head was suspected and the left eye excised by Mr. Scott on June 30th, 1927.

Pathological Report.-Fig. 2 shows a hemispherical neoplasm arising from the optic nerve head and infiltrating the retina on the temporal side. Its diameter is $4.5 \mathrm{~mm}$. and it is $1.5 \mathrm{~mm}$. from its base to the highest point on the summit. The neoplasm has a greyish colour and its consistency on cutting resembles that of the optic nerve.

Fig. 3 is a section through the growth at its summit. It is composed of irregular-shaped clumps and sweeping bundles of neurocytes and neurofibrils. Many small cysts are evident, some being roughly circular and others oval, irregular and cleft-like. These are disposed singly, some approximate each other, and at one site there is a cluster of seven small round cysts. The branches of the central retinal vessels traverse the neoplasm and apart from some 
congestion in the larger veins they show no pathological features. Areas of hyaline degeneration are present.

Fig. 4 shows the infiltration of the retina to the temporal side of the optic disc. The growth has invaded all the layers of the retina and the advancing edge has wedged itself laterally between the nuclear layers. At its base the layer of rods and cones has been destroyed, and the retinal pigment epithelium and the choroid are compressed. Fig. 4 shows degenerative changes in the rods and cones beyond the temporal limit of the neoplasm. Over this area many cone nuclei have been extruded through the external limiting membrane into the layer of rods and cones. On the temporal side in the molecular layer there are some small irregular masses of exudate and many swollen cells, arranged in clumps having a faintly granular cytoplasm and an eccentric nucleus. Exudates are also present in the outer molecular layer for a distance of $1 \mathrm{~mm}$. from the optic disc on the nasal side.

The lamina cribrosa is normal in structure and position and is not infiltrated by the neoplasm. The choroid beneath the growth on the temporal side has some condensation of its stroma and areas of hyaline degeneration. Figs. 5 and 6 are microphotographs of the nasal edge of the neoplasm and of its base.

\section{Pathological Diagnosis.-Neuroma of the optic nerve head.}

The patient's progress was uneventful until October, 1929, when he first noticed unsteadiness of gait, impaired hearing on the right side, nervousness and attacks of blurred vision in his remaining eye. The impaired hearing became progressively worse and about the middle of May, 1930, he began to suffer from frequent attacks of temporary blindness lasting for half a minute and generalised headaches on rising in the morning. Since June 1st, 1930, he had shown mental disturbance making absurd statements and laughing unreasonably at times. His gait had become unsteady.

The right eye showed coarse nystagmus in all directions and there was well marked papilloedema of the type associated with raised intracranial pressure, but there were no haemorrhages or exudates. The right vision was $6 / 9$.

The late Mr. Theodore Just made an aural examination and noted right middle ear deafness and was inclined to locate the intracranial lesion in the left posterior fossa. An examination of the remainder of the central nervous system, Wassermann reaction and Sigma reaction did not reveal any abnormality. On June 14th, 1930, he became more ataxic, walking on a wide base, was unable to stand on one leg but had no definite tendency to fall to one side. 
On June 16th he had a severe generalised headache and one attack of projectile vomiting. The blood pressure rose from 145/90 on June 3rd to 170 systolic on June 20th.

On June 21st Mr. Paterson Ross performed sub-occipital exploration but had to abandon the operation after a bilateral sub-tentorial decompression and tapping the left lateral ventricle, on account of low blood pressure and the condition of the patient. Cerebro-spinal fluid came through the trocar inserted in the left ventricle under considerable pressure and it was noted that the cortex was very thin. After operation the temperature rose to $104^{\circ} \cdot 2$, the pulse to 140 and respiration rate 25 . On the following day the temperature fell from $103^{\circ} .4$ to $101^{\circ} .2$ in the afternoon but rose again in the evening to $102^{\circ} .8$; the pulse ascended to 160 on the evening of this day and the respiration rate to 40 . He died early on the following morning, the second day after operation and unfortunately the relations refused to allow a post-mortem examination.

Commentary.-I have been unable to obtain histological verification about the precise nature of the multiple neoplasms which affected E.G.S. in the first generation and those affected in the second generation with the exception of Donald who died after an intra-cranial operation in the London Hospital and was found at post-mortem examination to have multiple neurofibromata, a few pigmented hairy papillomata in the skin of the ventral wall of the chest and abdomen, some café au lait patches, a faint generalised brownish pigmentation of the skin and a few small subcutaneous nodules on the trunk. Also I have been unable to trace authentic medical information about the cause of death in two infants in the second generation.

In this family there seems to have been a predilection for the multiple neoplasms to affect the central nervous system and particularly the nerves serving the special senses of sight and hearing. As the main clinical features of the disease affecting certain members of these three generations have considerable similarity, it is I think justifiable to assume that the pathological lesion was of the same character in all of them.

It is regrettable that details of complete post-mortem examinations in all these cases have not been available. It is interesting to note that 4 out of the 6 who were affected died between the ages of $18 \frac{1}{2}$ and $30 \frac{1}{2}$, the other 2 at 49 and 38 years of age respectively. The incidence of visual failure, deafness, ataxia, paralysis, epilepsy and mental symptoms is to be seen at a glance in Table A.

Intra-ocular lesions in von Recklinghausen's disease are very rare. They are briefly mentioned in the literature but $I$ have not found any statistical record of their incidence in this disease. 


\section{Summary}

A case of neuroma affecting the optic nerve head of the left eye in a young man, aged 19 years, is reported. His family history showed that in the two generations preceding his there were cases of multiple neurofibromata affecting the central nervous system and the nerves serving the special senses of sight and hearing. The histo-pathology of the neoplasm affecting the optic nerve head is described and microphotographs illustrating these changes are shown. Three years after the disease had been discovered in his left eye he developed signs of raised intracranial pressure from a neoplasm or possibly several neoplasms inside the skull. The right auditory nerve was involved. A subtentorial decompression was followed two days later by death.

I thank Mr. Rupert Scott for his permission to publish this case.

\section{LITERATURE}

Achermann, E.-Zeitschr.f. Augenheilk., Vol. LXVII, p. 141, 1929.

Aliquo-MaZZEi, A.-Lett. Oftal. Vol. XIL. p. 367, 1934. Abstracted Amer. Jl. Ophthal. Vol. XVIII. p. 294, 1935.

Callendar, G.R. and ThigPen, C. A.-Amer. Jl. Ophthal Vol. XIII, p, 121, 1930.

Collins, E. Treacher, and Rayner Batten. Trans. Ophthal. Soc. U.K., Vol. XXV, p. $248,1905$.

Copeland, M. M. Craver, L. F., and Reese, A. B.-Arch. Surg. Vol. XXIX, p. $108,1934$.

Foster, J. and Polsen, C.-Proc. Roy. Soc. Med., Vol. XXVII, pt. 2, 94, 1934.

Goldstein, I. and WexLeR, D.-Arch. of Opthal.pp. 111, 288, 1930. Ibid., Vol. VII, p. 259, 1932.

Halbertsma, K. T. A.-Arch. of Ophthal. Vol. CXXXIV, p. 167, 1935. Abstracted Amer. Jl. Opthal. Vol. XIX, p. 76, 1936.

Hine, M. L. and WyatT, R. B. H., Brit. Jl. Ophthai., Vol. XII, p. 513, 1928.

Krotkov, H., Golubera, K. and Fioletov, S., Sov. Viest. Opht., Vol. V, p. 248. Abstracted Amer. Jl. Ophthal. Vol. XVIII, p. 405, 1935.

Moore, R. Foster, Brit. Jl. Ophthal. Vol. XV, p. 272, 1931.

Parsons, J. H.-The Pathology of the Eye, Vol. II, Part 2, pp. 492 and 730, 1905.

Parsons, J. H. and RocklifFe.-Trans Path. Soc., Vol. LV, p. 27, 1904.

ShaPLAND, C. D. and GREENFIELD, J. G.-Trans. Ophthal. Soc.U.K., Vol. LV, p. $257,1935$.

SNELL, S.-Trans. Ophthal. Soc. U.K., Vol. XXIII, p. 1571903.

Soriano, F. J. and PIColi, H.-Arch.de Oftal.. Vol. X, p. 620, 1935. Abstracted Amer. Jl. Ophthal., Vol. XIX, p $280,1936$.

Tномson, A.-Neuroma and Neurofibromatosis, Edinburgh, 1900.

VAN Der Hoeve, J. - Jl. Belge de Neurol. et de Psychiat., Vol. XXXIII, p. 752,1933. 